\title{
UJI DAYA HAMBAT MINYAK DAUN CENGKEH DAN EKSTRAK DAUN PEPAYA TERHADAP CENDAWAN Alternaria solani (Ell. \& Mart.) Sorauer PADA TOMAT SECARA IN VITRO
}

\section{INHIBITORY TEST OF CLOVE LEAF OIL AND PAPAYA LEAF EXTRACT AGAINST Alternaria solani (Ell. \& Mart.) Sorauer IN TOMATO BY IN VITRO}

\author{
Sintia Dewi Hizrianti ${ }^{1}$, Dedi Natawijaya ${ }^{1}$, Adam Saepudin ${ }^{1}$ \\ ${ }^{1}$ Program Studi Agroteknologi Fakultas Pertanian Universitas Siliwangi \\ Jalan Siliwangi No. 24 Kotak Pos 164 Kode Pos 46115 Tasikmalaya
}

Korespondensi : dedinatawijaya@unsil.ac.id

\begin{abstract}
ABSTRAK
Tanaman tomat (Solanum lycopersicum L.) merupakan salah satu komoditas hortikultura yang rentan terserang penyakit. Penyakit yang dapat menyebabkan tanaman tomat kehilangan hasil hingga mencapai $86 \%$ adalah penyakit bercak coklat yang disebabkan oleh cendawan patogen Alternaria solani. Penelitian ini bertujuan untuk mengetahui pengaruh minyak daun cengkeh dalam menghambat pertumbuhan cendawan A. solani. Percobaan dilaksanakan pada bulan Agustus 2020 sampai Januari 2021 di Laboratorium Fakultas Pertanian Universitas Siliwangi. Metode yang digunakan yaitu metode eksperimen dengan menggunakan Rancangan Acak Lengkap (RAL) yang terdiri dari 5 perlakuan dan diulang sebanyak 5 kali. Hasil uji pendahuluan menunjukkan bahwa perlakuan minyak daun cengkeh dengan konsentrasi $0,065 \%, 0,08 \%$, dan $0,095 \%$ dapat menghambat pertumbuhan miselium cendawan A. solani dengan persentase penghambatan sebesar $100 \%$, sedangkan untuk perlakuan ekstrak daun pepaya pada konsentrasi $15 \%, 30 \%$ dan $45 \%$ secara berturut-turut menunjukkan nilai persentase penghambatan sebesar $-9 \%$, 9\%, dan 40\%. Minyak daun cengkeh dengan konsentrasi $0,065 \%$ menunjukkan penghambatan tertinggi terhadap pertumbuhan miselium cendawan $A$. solani dibandingkan dengan perlakuan konsentrasi yang lain.
\end{abstract}

Kata kunci: Alternaria solani, Ekstrak Daun Pepaya, Minyak Daun Cengkeh

\begin{abstract}
Tomato (Solanum lycopersicum L.) is a horticultural commodity that is susceptible to disease. The disease that causes tomato plants to lose up to $86 \%$ of yield is brown spot disease caused by the pathogenic fungus Alternaria solani. This study aims to determine the effect of clove leaf oil in inhibiting the growth of A. solani. The experiment was carried out from August 2020 to January 2021 at the Laboratory of the Faculty of Agriculture, Siliwangi University. The method used was an experimental method using a Completely Randomized Design consisting of 5 treatments and repeated 5 times. Preliminary test results showed that the treatment of clove leaf oil with a concentration of $0.065 \%, 0.08 \%$, and $0.095 \%$ could inhibit the growth of $A$. solani mycelium with $100 \%$ inhibition, while papaya leaf extract at a concentration of $15 \%, 30 \%$ and $45 \%$ showed percentage inhibition of $-9 \%, 9 \%$, and $40 \%$ respectively. Clove leaf oil with concentration of $0,065 \%$ showed the highest inhibition against mycelium growth of $A$. solani compared with the other concentrations.
\end{abstract}

Keywords : Alternaria solani, Clove Leaf Oil, Papaya Leaf Extract 


\section{PENDAHULUAN}

Tanaman tomat (Solanum lycopersicum L.) adalah salah satu komoditas hortikultura yang rentan terserang penyakit. Salah satu penyakit yang sering menyerang tanaman tomat adalah penyakit bercak coklat (early blight disease) yang disebabkan oleh cendawan patogen Alternaria solani (Ell. \& Mart.) Sorauer. Patogen ini dapat menyerang seluruh bagian tanaman tomat seperti daun, batang, dan buah, dan menyebabkan kerusakan parah pada setiap tahapan perkembangan tanaman. Serangan cendawan A. solani sangat berpengaruh terhadap berkurangnya kualitas maupun kuantitas hasil tanaman (Nashwa dan Abo-Elyou, 2012 dan Istifadah dan Hakim, 2017). Tanaman yang terserang dapat mengalami kehilangan hasil hingga 86\% (Kalay et al., 2015). Selain pada tanaman tomat, A. solani juga dapat menginfeksi tanaman famili solanaceae lain seperti cabai, kentang dan terung (Rukmana dan Saputra, 1997 dalam Kalay et al., 2015).

Gejala penyakit bercak coklat yaitu berupa timbulnya bercak berwarna coklat pada daun yang berbentuk konsentris dan dikelilingi klorosis daun berwarna kuning (Setiawan, 2019). Apabila menyerang pangkal batang akan muncul bercak cokelat berbentuk konsentris sehingga menyebabkan batang menjadi busuk dan serangan pada buah dapat menyebabkan munculnya luka di permukaan buah (Abada et al, 2008 dalam Nashwa dan Abo-Elyou, 2012). Bahkan pada serangan yang parah dapat menyebabkan daun kering dan buah yang terinfeksi menjadi rontok (Semangun, 2007 dalam Istifadah dan Hakim, 2017). A. solani sering menyerang bagian daun yang sudah tua, hal tersebut diduga karena daun yang sudah tua mengandung lebih banyak nutrisi sehingga spora $A$. solani dapat mudah berkecambah (Widhayasa et al., 2014).

Cara pengendalian penyakit bercak coklat biasa dilakukan dengan penyemprotan pestisida sintetik. Secara umum, pestisida sintetik mengandung bahan kimia yang bersifat racun sehingga apabila penggunaan tidak dilakukan dengan baik dan benar akan beresiko menimbulkan dampak buruk terhadap berbagai aspek, seperti kesehatan manusia karena pada saat mengaplikasikan petani tidak menggunakan peralatan dan perlengkapan yang baik dan benar, organisme yang menguntungkan dapat ikut musnah karena penggunaan dosis yang tidak sesuai, munculnya patogen yang resisten terhadap pestisida jenis tertentu, selain itu beresiko mengakibatkan pencemaran lingkungan apabila penggunaan pestisida sintetik dilakukan secara terus-menerus dalam jangka waktu yang panjang (Singkoh dan Katili, 2019). Dalam upaya menghindari berbagai resiko dampak buruk yang terjadi apabila penggunaan pestisida sintetik terus dilakukan, maka penggunaan pestisida sintetik perlu dikurangi. Oleh karena itu, pencarian alternatif lain yang dapat dijadikan pengganti pestisida sintetik dalam mengendalikan serangan penyakit pada tanaman khususnya penyakit bercak coklat pada tanaman tomat harus dilakukan. Salah satu alternatif untuk mengatasi hal itu adalah dengan pengembangan pestisida berbahan dasar tumbuhan atau yang dikenal sebagai pestisida nabati.

Pengembangan pestisida nabati penting dilakukan karena memiliki berbagai macam kelebihan, diantaranya ramah lingkungan, tidak meracuni tanaman, tidak menimbulkan resistensi hama, dan tidak menyisakan residu kimia yang berbahaya pada produk pertanian, sehingga tidak membahayakan kesehatan manusia (Irfan, 2016). Selain memiliki berbagai macam kelebihan, pestisida nabati juga memiliki beberapa kelemahan yaitu memiliki reaksi yang relatif lambat dalam mengendalikan OPT, bahan baku relatif terbatas, dan tidak dapat disimpan dalam waktu yang lama. Selain itu, perizinan untuk mengedarkan dan memperjualbelikan juga sulit didapat, hal ini semakin menghambat pengembangan 
pestisida nabati di Indonesia (Kardinan, 2011). Meskipun demikian, percobaan dan penelitian mengenai potensi penggunaan pestisida nabati dalam mengendalikan hama dan penyakit tanaman tetap banyak dilakukan. Suhartini et al. (2017) melaporkan bahwa tembakau, daun sirih, daun kayu kuning dan tapak liman memiliki pengaruh terhadap mortalitas Plutella xylostella. Selain itu, Setiawan dan Oka (2015) mengatakan daun pepaya berpotensi dijadikan pestisida nabati karena dapat menyebabkan mortalitas terhadap kutu daun kacang panjang pada dosis $35 \mathrm{~g} / \mathrm{L}$ daun pepaya dengan tingkat mortalitas sebesar $92 \%$ pada 24 jam setelah aplikasi. Pada penelitian lain disebutkan bahwa minyak daun cengkeh dan serai wangi cukup stabil dan efektif dalam mengendalikan penyakit bercak daun pada tanaman jahe, karena pada konsentrasi 0,2\% campuran kedua minyak atsiri ini dapat menekan tingkat serangan hingga di bawah 10\% (Hartati, 2012).

Tumbuhan memiliki potensi sebagai pestisida nabati disebabkan karena tumbuhan mensintesis senyawa yang disebut dengan metabolit sekunder yang memiliki potensi untuk menekan pertumbuhan patogen. Metabolit sekunder tersebut dapat berupa alkaloid, terpenoid, fenol, flavonoid, minyak atsiri, tanin, dan lain sebagainya (Tampubolon et al., 2018). Kandungan minyak atsiri pada cengkeh dapat diisolasi dari bagian bunga (10 sampai 20\%), tangkai (5 sampai 10\%) maupun daun (1 sampai 4\%), dengan kandungan eugenol mencapai 70 sampai $80 \%$ (Nurdjannah, 2004). Rana, et al. (2011) mengungkapkan bahwa kandungan eugenol pada minyak daun cengkeh mempunyai sifat antifungi pada cendawan Fusarium moniliforme NCIM 1100, Fusarium oxysporum MTCC 284, dan Aspergillus sp.. Aktivitas antifungi minyak daun cengkeh juga terbukti mampu menghambat pertumbuhan dan biomassa cendawan Botryodiplodia sp. secara in vitro dengan rata-rata penghambatan sebesar 45,44\% pada media PDA (Radilla, 2019).

Daun pepaya (C. papaya) terbukti mengandung alkaloid, triterpenoid, steroid, flavonoid, saponin, dan tanin melalui analisis fitokimia (A'yun dan Laily, 2015). Senyawasenyawa tersebut merupakan metabolit sekunder yang dihasilkan tanaman dan dapat digunakan sebagai alat pertahanan dari serangan organisme pengganggu (Zulkipli et al., 2018). Ekstrak daun pepaya efektif untuk mengendalikan Aphis gossypii pada konsentrasi $30 \%$ yang menyebabkan mortalitas 80,66\% (Ramadhona, 2016). Ekstrak metanol daun pepaya memiliki komponen fungitoksik yang mampu menghambat pertumbuhan miselium jamur $A$. solani asal busuk umbi pada ubi jalar (Suleiman, 2010). Baskaran et al. (2012) melaporkan bahwa ekstrak aseton daun pepaya mampu menghambat jamur Candida albicans penyebab penyakit kandidiasis pada manusia.

Berdasarkan kandungan yang terdapat di dalam minyak daun cengkeh dan daun pepaya yang memiliki sifat antifungi, maka kedua bahan pestisida nabati ini memiliki potensi dapat mengendalikan pertumbuhan cendawan A. solani. Selain itu karena pengujian daya hambat minyak daun cengkeh dan ekstrak daun pepaya dalam menghambat cendawan patogen A. solani belum banyak dilaporkan, maka diperlukan penelitian untuk menguji potensi minyak daun cengkeh dan ekstrak daun pepaya dalam menghambat pertumbuhan cendawan $A$. solani penyebab penyakit bercak coklat pada tomat secara in vitro.

\section{BAHAN DAN METODE}

Penelitian ini dilaksanakan di Laboratorium Proteksi Tanaman Fakultas Pertanian Universitas Siliwangi Tasikmalaya dari Agustus 2020 sampai dengan Januari 2021.

Alat yang digunakan meliputi erlenmeyer, cawan petri, gelas ukur, gelas piala, pipet ukur, pipet mikro, spatula, jarum 
ose, lampu bunsen, plastik tahan panas, blender, autoklaf, kompor gas, timbangan, aluminum foil, plastik wrap, timbangan analitik, kapas, kain kasa, jangka sorong, mikroskop dan laminar air flow. Sementara itu, bahan yang digunakan meliputi minyak daun cengkeh, ekstrak daun pepaya biakan murni Alternaria solani, daun tomat, PDA, $\mathrm{CaCO}_{3}$, sukrosa, agar teknis, alkohol 70\%, metanol, spirtus, tween 20, dan akuades.

\section{Rancangan Percobaan Uji Pendahuluan}

Percobaan yang dilakukan pada uji pendahuluan yaitu dengan penggunaan beberapa tingkat konsentrasi minyak daun cengkeh dan ekstrak daun pepaya untuk menentukan konsentrasi yang akan digunakan pada uji lanjutan. Perlakuan konsentrasi yang digunakan pada uji pendahuluan adalah sebagai berikut:

$\begin{array}{ll}\text { Kontrol } & =0 \% \\ \text { Minyak daun cengkeh } & =0,065 \% \\ \text { Minyak daun cengkeh } & =0,080 \% \\ \text { Minyak daun cengkeh } & =0,095 \% \\ \text { Ekstrak daun pepaya } & =15 \% \\ \text { Ekstrak daun pepaya } & =30 \% \\ \text { Ekstrak daun pepaya } & =45 \%\end{array}$

\section{Rancangan Percobaan Uji Lanjutan}

Percobaan dilakukan menggunakan metode eksperimental dengan Rancangan Acak Lengkap (RAL) dengan 5 perlakuan yang diulang 5 kali, sehingga diperoleh 25 unit percobaan. Perlakuan yang diberikan adalah konsentrasi minyak daun cengkeh sebagai berikut:
$\mathrm{A}=$ Kontrol $(0 \%)$
B = Minyak Daun Cengkeh 0,020\%
$\mathrm{C}=$ Minyak Daun Cengkeh $0,035 \%$
D = Minyak Daun Cengkeh 0,050\%
$\mathrm{E}=$ Minyak Daun Cengkeh 0,065\%

\section{Sterilisasi Alat}

Metode yang umum digunakan dalam sterilisasi alat laboratorium adalah metode panas lembab menggunakan autoklaf. Semua peralatan yang akan digunakan dicuci, lalu dikeringanginkan, dibungkus dengan kertas dan plastik tahan panas. Kemudian disterilisasi pada suhu $121{ }^{\circ} \mathrm{C}$ selama 15 menit.

\section{Pembuatan Media Tanam dan Media Perlakuan}

Media yang digunakan untuk peremajaan biakan cendawan dan untuk media perlakuan adalah media potato dextrose agar (PDA) Merck 1.10130.0500. Pembuatan media dilakukan dengan cara melarutkan $39 \mathrm{~g}$ media PDA ke dalam $1000 \mathrm{ml}$ aquades. Larutan dipanaskan dan diaduk di atas hot plate magnetic stirrer hingga homogen. Kemudian, disterilisasi menggunakan autoklaf pada suhu $121^{\circ} \mathrm{C}$ selama 20 menit. Media tanam cendawan A. solani yang telah disterilisasi dituangkan ke dalam cawan petri steril sebanyak $10 \mathrm{ml}$ per cawan.

Pada media perlakuan, media PDA diberi campuran minyak daun cengkeh dan ekstrak daun pepaya sesuai dengan konsentrasi perlakuan. Pemberian minyak daun cengkeh dan ekstrak daun pepaya dilakukan dengan cara mengambil minyak daun cengkeh dan ekstrak daun pepaya sesuai konsentrasi lalu dimasukkan ke dalam cawan petri, kemudian media PDA ditambahkan hingga volume larutan mencapai $10 \mathrm{ml}$. Selanjutnya cawan petri digoyangkan perlahan, agar larutan media tercampur homogen dengan minyak daun cengkeh dan ekstrak daun pepaya.

\section{Peremajaan Cendawan Patogen}

Biakan murni cendawan patogen A. solani diperoleh dari Balai Penelitian Tanaman Sayuran Lembang, Jawa Barat. Biakan tersebut diremajakan dengan cara mengambil 1 cork borer (diameter $0,5 \mathrm{~cm}$ ) dari media asal kemudian diinokulasikan ke media PDA baru yang telah dibuat lalu diinkubasi pada suhu ruang hingga miselium tumbuh (modifikasi dari Wahyuni, 2004 dan Setiawan, 2019). 


\section{Penyiapan Minyak Daun Cengkeh}

Minyak daun cengkeh diperoleh dari produsen minyak daun cengkeh di Dayeuhluhur, Cilacap, Jawa Tengah. Minyak daun cengkeh tersebut kemudian diencerkan sebelum digunakan sebagai perlakuan. Pengenceran dilakukan dengan menggunakan pengemulsi sebanyak $0,2 \%$ karena minyak daun cengkeh tidak dapat larut dalam air (Dadang dan Prijono, 2008). Pengemulsi yang digunakan adalah larutan tween $20(0,2 \% \mathrm{v} / \mathrm{v})$. Minyak daun cengkeh diencerkan hingga kepekatan $1 \%(\mathrm{v} / \mathrm{v})$ untuk memudahkan dalam proses uji daya hambat karena konsentrasi minyak daun cengkeh yang diperlukan kurang dari $1 \%$.

\section{Pembuatan Ekstrak Daun Pepaya}

Daun pepaya diperoleh dari wilayah Tamansari kota Tasikmalaya. Sebelum dihaluskan daun terlebih dahulu dicuci kemudian bagian tulang daun dibuang dan daun dipotong-potong kecil dengan tujuan untuk memudahkan proses pengeringan. Daun yang telah dipotong dikeringkan menggunakan oven pada suhu $50^{\circ} \mathrm{C}$ sampai daun benar-benar kering hingga bisa dijadikan serbuk (simplisia). Daun yang sudah kering dihaluskan dengan menggunakan blender, lalu diayak menggunakan saringan yang memiliki lubang halus sehingga diperoleh serbuk daun pepaya yang halus untuk kemudian diekstraksi. Metode ekstraksi dilakukan dengan metode refluks (Nugroho et al. 2017). Daun pepaya kering $(450 \mathrm{~g})$ diekstraksi sebanyak 3 kali menggunakan larutan metanol (3 L) dibawah refluks pada suhu $70{ }^{\circ} \mathrm{C}$ selama 5 jam. Hasil ekstraksi disaring menggunakan kertas saring dan diuapkan menggunakan rotary evaporator agar didapat ekstrak kental dengan massa $43 \mathrm{~g}$. Pembuatan ekstrak ini dilakukan di Laboratorium Farmasi Universitas Garut.

\section{Uji Patogenisitas Alternaria solani}

Uji patogenisitas dilakukan dengan mengikuti metode Detached Leaves Assay (DLA). Mula-mula daun tomat disterilisasi permukaan dengan cara merendam daun dalam alkohol $70 \%$ selama 1 menit dan dalam larutan natrium hipoklorit $(\mathrm{NaOCl})$ 2,5\% selama 2 menit. Setelah itu, daun dibilas dengan aquades steril sebanyak 3 kali (Hallmann et al., 1997 dalam Munif et al., 2012). Daun yang telah disterilisasi permukaannya disimpan di cawan petri steril yang telah dialasi tisu yang basah agar kelembaban daun terjaga. Permukaan daun memiliki dua sisi yang dipisahkan oleh tulang daun utama, pada kedua sisi tersebut diinokulasikan potongan media PDA yang berbeda, pada satu sisi daun diinokulasikan potongan media yang dipenuhi miselium cendawan A. solani dan pada sisi daun yang lain diinokulasikan potongan media PDA yang tidak ditumbuhi miselium cendawan $A$. solani. Potongan media PDA yang diambil adalah sebanyak 1 cork borer berdiameter $0,5 \mathrm{~cm}$. Uji patogenisitas ini dilakukan secara duplo (dua kali ulangan).

\section{Uji Pendahuluan}

Uji pendahuluan dilakukan dengan tujuan untuk mendapatkan konsentrasi perlakuan yang akan digunakan pada uji lanjutan. Pengujian dilakukan dengan menguji beberapa tingkat konsentrasi minyak daun cengkeh dan ekstrak daun pepaya untuk diketahui nilai persentase penghambatannya terhadap pertumbuhan miselium cendawan A. solani. Persentase penghambatan (PP) dihitung dengan menggunakan rumus yang digunakan oleh Wahyuni (2004), yaitu:

$$
P P=\frac{d 1-d 2}{d 1} \times 100 \%
$$

Keterangan:

$\mathrm{PP}=$ persentase penghambatan; $\mathrm{d} 1=$ diameter koloni kontrol; $\mathrm{d} 2$ = diameter koloni perlakuan 


\section{Uji Daya Hambat}

Uji daya hambat minyak daun cengkeh dilakukan dengan teknik peracunan makanan (poisoned food technique) mengacu pada metode yang digunakan oleh Balouiri et al. (2016), yaitu minyak daun cengkeh $(1 \%)$ dicampurkan kedalam PDA yang masih cair hingga mencapai konsentrasi sesuai perlakuan. Kemudian media dibiarkan hingga memadat. Pada uji daya hambat ekstrak daun pepaya metode yang digunakan mengacu pada Achmad \& Suryana (2009) yaitu dengan mengencerkan ekstrak daun pepaya sesuai dengan konsentrasi yang telah ditentukan, kemudian dari masing-masing konsentrasi ekstrak tersebut diambil sebanyak $2 \mathrm{ml}$ dan dicampurkan kedalam $10 \mathrm{ml}$ PDA yang masih cair. Lalu media dibiarkan hingga memadat. Selanjutnya biakan cendawan $A$. solani diambil sebanyak 1 cork borer lalu diinokulasikan ke bagian tengah media. Semua kegiatan dilakukan secara aseptik di dalam Laminar Air Flow. Media yang telah diinokulasikan cendawan A. solani diinkubasi pada suhu ruang $\left(25{ }^{\circ} \mathrm{C}\right)$. Miselium cendawan A. solani diukur setiap 24 jam selama 7 hari menggunakan jangka sorong dan dihitung persentase penghambatannya seperti yang dilakukan pada uji pendahuluan.

\section{HASIL DAN PEMBAHASAN}

\section{Patogenisitas Cendawan Alternaria solani}

Uji patogenisitas dilakukan untuk mengetahui virulensi cendawan pada daun tomat. Secara umum, hasil dari pengujian patogenisitas cendawan Alternaria solani ini tidak menunjukkan gejala yang sama dengan yang terjadi di lapangan, yaitu munculnya bercak coklat yang disertai halo berwarna kuning di sekelilingnya (Setiawan, 2019). Banyak faktor yang diduga menyebabkan gejala penyakit tidak nampak. Salah satunya adalah karena cendawan $A$. solani yang digunakan dalam penelitian ini tidak mengalami pembentukan konidia. Tidak adanya konidia cendawan yang diinokulasikan pada permukaan daun tomat sebagai bahan uji ini diduga menjadi faktor utama yang menyebabkan tidak munculnya gejala penyakit bercak coklat pada daun tomat tersebut.

Faktor lain seperti lingkungan dan inang (daun tomat yang digunakan) sudah dikondisikan agar sesuai dengan lingkungan hidup cendawan A. solani. Setelah cendawan diinokulasikan pada daun tomat, toples berisi daun tomat tersebut disimpan disuhu ruang $\left(25^{\circ} \mathrm{C}\right)$ dengan pencahayaan gelap/terang masing-masing selama 12 jam. Menurut Ravikumar et al. (2016), A. solani memiliki kemampuan dalam menginfeksi tanaman tomat dalam kondisi kering maupun basah (lembab) dan dapat tumbuh dalam jangkauan suhu yang luas sekitar 4 sampai $36^{\circ} \mathrm{C}$. Daun tomat yang digunakan juga daun tomat tua yang sudah berwarna hijau tua dan berukuran lebih besar dibanding daun tomat lain pada tanaman yang sama. Daun tomat berumur tua digunakan karena pada dasarnya penyakit bercak coklat penyakit yang menyerang jaringan yang berumur tua (Widhayasa et al., 2014).

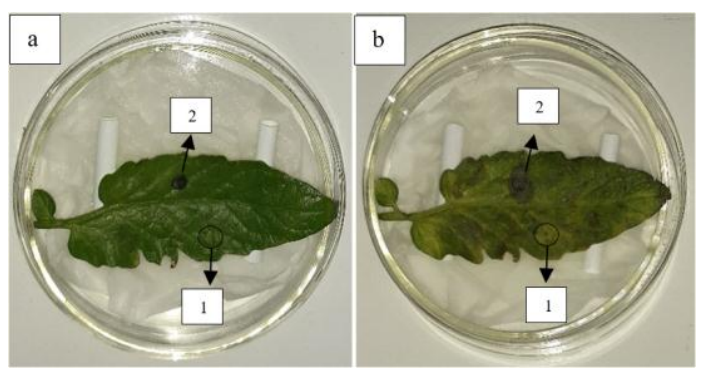

Gambar 1. Patogenisitas A. solani

Keterangan: (a) Kondisi daun awal; (b) Kondisi daun 2 HSI; (1) Potongan media PDA; (2) Potongan miselium cendawan A. solani

Kondisi awal daun yang digunakan pada uji patogenisitas ini berwarna hijau segar (gambar 1.a). Pada 2 hari setelah miselium cendawan A. solani diinokulasikan kondisi 
daun menjadi lebih layu disebabkan oleh faktor fisiologis dari daun tersebut. Selain itu, muncul bercak coklat di sekitar potongan miselium cendawan A. solani yang ditunjukkan oleh gambar 1.b no. 2. Bercak coklat tersebut berbentuk agak lonjong dan hanya terdapat di sekitar potongan miselium cendawan A. solani. Pada potongan PDA yang murni (no. 1) di sekelilingnya tidak terdapat bercak. Hal tersebut membuktikan bahwa cendawan A. solani ini menyebabkan penyakit terhadap daun yang ditandai dengan munculnya bercak coklat tersebut.
Maka dari itu, dapat disimpulkan bahwa cendawan A. solani yang digunakan pada penelitian ini bersifat patogen meskipun tidak menunjukkan gejala yang sama dengan gejala yang muncul di lapangan.

\section{Uji Pendahuluan}

Uji pendahuluan ini dilakukan untuk menentukan konsentrasi yang akan digunakan dalam uji lanjutan. Data diameter koloni cendawan $A$. solani disajikan pada tabel berikut ini.

Tabel 1. Diameter koloni cendawan Alternaria solani pada uji pendahuluan

\begin{tabular}{|c|c|c|c|c|c|c|c|c|}
\hline \multirow{2}{*}{ Perlakuan } & \multirow{2}{*}{$\begin{array}{c}\text { Konsentrasi } \\
(\%)\end{array}$} & \multicolumn{7}{|c|}{ Diameter Koloni $(\mathrm{cm})$ pada hari ke- } \\
\hline & & 1 & 2 & 3 & 4 & 5 & 6 & 7 \\
\hline Kontrol & 0 & 0,59 & 2,01 & 2,45 & 2,78 & 3,01 & 3,17 & 3,35 \\
\hline \multirow{3}{*}{$\begin{array}{l}\text { Minyak } \\
\text { daun } \\
\text { cengkeh }\end{array}$} & 0,065 & 0 & 0 & 0 & 0 & 0 & 0 & 0 \\
\hline & 0,080 & 0 & 0 & 0 & 0 & 0 & 0 & 0 \\
\hline & 0,095 & 0 & 0 & 0 & 0 & 0 & 0 & 0 \\
\hline \multirow{3}{*}{$\begin{array}{l}\text { Ekstrak } \\
\text { daun } \\
\text { pepaya }\end{array}$} & 15 & 0,10 & 0,70 & 1,14 & 1,79 & 2,47 & 3,06 & 3,64 \\
\hline & 30 & 0,00 & 0,50 & 0,85 & 1,32 & 1,78 & 2,36 & 3,04 \\
\hline & 45 & 0,00 & 0,00 & 0,32 & 0,65 & 0,96 & 1,49 & 2,01 \\
\hline
\end{tabular}

Tabel 2. Persentase penghambatan minyak daun cengkeh dan ekstrak daun pepaya terhadap pertumbuhan miselium cendawan Alternaria solani

\begin{tabular}{lcccccccc}
\hline \multirow{2}{*}{ Perlakuan } & $\begin{array}{c}\text { Konsentrasi } \\
(\%)\end{array}$ & \multicolumn{7}{c}{ Persentase penghambatan (\%) pada hari ke- } \\
\cline { 3 - 10 } & 0,065 & 100 & 100 & 100 & 100 & 100 & 100 & 100 \\
Minyak & 0,080 & 100 & 100 & 100 & 100 & 100 & 100 & 100 \\
daun & 0,095 & 100 & 100 & 100 & 100 & 100 & 100 & 100 \\
cengkeh & 15 & 84 & 65 & 53 & 35 & 18 & 4 & -9 \\
& 30 & 100 & 75 & 65 & 52 & 41 & 25 & 9 \\
Ekstrak & 45 & 100 & 100 & 87 & 77 & 68 & 53 & 40 \\
daun pepaya & & & & & & & & \\
& & &
\end{tabular}

Berdasarkan Tabel 1 dapat diketahui bahwa seluruh perlakuan konsentrasi minyak daun cengkeh mampu menghambat pertumbuhan miselium cendawan A. solani hingga miselium sama sekali tidak tumbuh hingga akhir pengamatan. Persentase penghambatan (tabel 2) juga menunjukkan penghambatan sebesar 100\% untuk semua perlakuan minyak daun cengkeh dari awal hingga akhir pengamatan. Untuk melihat potensi penghambatan yang lebih bervariasi, maka pada uji lanjutan konsentrasi 0,065\% dijadikan sebagai acuan untuk menetapkan konsentrasi lain yang akan dijadikan sebagai perlakuan. Konsentrasi 0,065\% ini dijadikan sebagai konsentrasi tertinggi dalam perlakuan di uji lanjutan.

Perlakuan ekstrak daun pepaya menunjukkan penghambatan sebesar $40 \%$ pada konsentrasi $45 \%$, sedangkan pada 
konsentrasi $30 \%$ penghambatan yang ditunjukkan sangat kecil yaitu hanya sebesar 9\%. Bahkan, pada konsentrasi 15\% persentase penghambatan menunjukkan nilai yang negatif (-9\%). Perlakuan ekstrak daun pepaya ini diputuskan untuk tidak digunakan dalam uji lanjutan karena pada konsentrasi $15 \%$ saja tidak menunjukkan adanya kemampuan daya hambat dimana $15 \%$ merupakan konsentrasi yang cukup tinggi dalam uji in vitro. Mengacu pada Dadang dan Prijono (2008), mereka telah banyak melakukan penelitian di bidang pembuatan pestisida nabati ini dan mengatakan bahwa batas kelayakan konsentrasi untuk pengujian awal ekstrak bahan tumbuhan dengan pelarut organik dilakukan pada konsentrasi kurang dari $1 \%$ dan untuk ekstrak air kurang dari $10 \%$. Apabila pada pengujian awal konsentrasi ekstrak yang dibutuhkan lebih dari batas kelayakan tersebut maka tidak perlu diuji lebih lanjut karena akan membutuhkan lebih banyak bahan dan proses pembuatan akan lebih lama sehingga dinilai tidak ekonomis dan efisien lagi. Adapun ekstrak daun pepaya yang digunakan dalam uji pendahuluan ini diekstraksi menggunakan pelarut organik yaitu metanol maka konsentrasi yang dibutuhkan untuk uji lanjutan akan sangat melewati batas kelayakan yang direkomendasikan.

Perbedaan pengaruh yang diberikan oleh minyak daun cengkeh dan ekstrak daun pepaya dalam menghambat pertumbuhan cendawan $A$. solani disebabkan karena perbedaan kandungan yang dimiliki minyak daun cengkeh dan ekstrak daun pepaya. Minyak daun cengkeh mengandung senyawa eugenol (87,18\%) dan $\square$-caryophyllene $(8,76 \%)$ (Pratiwi et al., 2016). Senyawa eugenol sebagai kandungan utama dari minyak daun cengkeh memiliki kemampuan yang efektif dalam mengendalikan cendawan patogen (Wiratno, 2009 dalam Towaha, 2012).
Pada ekstrak daun pepaya senyawa metabolit sekunder yang dikandung diantaranya adalah alkaloid, flavonoid glikosida dan tanin (Mahatriny et al., 2014). Hal tersebut tidak sejalan dengan hasil penelitian Fauzi'ah \& Wakidah (2019) yang menyatakan bahwa kandungan pada ekstrak metanol daun pepaya menurut hasil analisis kromatografi gas-spektroskopi massa (KGSM) menunjukkan adanya neofitadiena $(1,59 \%)$, asam palmitat $(1,35 \%)$ dan metil linolenat $(3,33 \%)$. Neofitadiena merupakan metabolit sekunder kelas terpenoid (Ragasa \& Tsai, 2009). Metil linolenat merupakan metabolit pada tanaman yang memiliki peran sebagai penarik serangga, sedangkan asam palmitat merupakan asam lemak tak jenuh (Ozawa et al., 2008 dan Marfo et al., 1986 dalam Fauzi'ah \& Wakidah, 2019). Antara senyawa neofitadiena, asam palmitat dan metil linolenat yang memiliki sifat antifungi adalah senyawa neofitadiena karena merupakan salah satu golongan terpenoid. Terpenoid merupakan salah satu golongan metabolit sekunder yang memiliki sifat antifungi (Balafif et al., 2017). Rendahnya kandungan antifungi yang terkandung dalam ekstrak daun pepaya ini diduga menjadi penyebab kecilnya nilai persentase penghambatan ekstrak daun pepaya terhadap pertumbuhan cendawan $A$. solani.

\section{Daya Hambat Minyak Daun Cengkeh terhadap Cendawan Alternaria solani}

Daya hambat minyak daun cengkeh terhadap pertumbuhan miselium cendawan A. solani ditunjukkan dengan adanya perbedaan ukuran diameter koloni antara kontrol dan pemberian perlakuan minyak daun cengkeh, yaitu apabila diameter perlakuan lebih kecil dibanding diameter kontrol. Data hasil pengamatan pada Tabel 5 menunjukkan bahwa terjadi perbedaan pertumbuhan diameter koloni antara setiap perlakuan konsentrasi. Pada perlakuan 
kontrol dan konsentrasi $0,020 \%$ miselium cendawan mulai tumbuh pada 1 HSI dengan besaran ukuran diameter masing-masing $0,377 \mathrm{~mm}$ dan $0,053 \mathrm{~mm}$. Sedangkan pada konsentrasi $0,035 \%$ dan $0,050 \%$ miselium cendawan tumbuh pada 2 HSI dengan besaran ukuran diameter masing-masing $0,067 \mathrm{~mm}$ dan 0,029 $\mathrm{mm}$. Berbeda dari perlakuan konsentrasi yang lain, pada perlakuan konsentrasi $0,065 \%$ miselium cendawan tidak tumbuh hingga hari terakhir pengamatan. Berdasarkan data pada Tabel 5 juga dapat diketahui bahwa dari 1 HSI hingga 6 HSI diameter koloni perlakuan kontrol lebih besar dibanding diameter perlakuan konsentrasi lainnya. Hanya saja pada 7 HSI diameter koloni cendawan perlakuan konsentrasi $0,02 \%$ memiliki ukuran yang lebih besar dibanding perlakuan kontrol. Hal tersebut menunjukkan laju pertumbuhan miselium cendawan dengan perlakuan konsentrasi $0,02 \%$ meningkat pada hari ke 7 setelah inokulasi.
Perbedaan diameter koloni cendawan antar perlakuan diuji secara statistik untuk diketahui apakah perbedaan tersebut berbeda nyata atau tidak. Perlakuan yang menunjukkan pengaruh yang nyata dan memiliki daya hambat terbesar adalah perlakuan konsentrasi $0,065 \%$, perlakuan ini menyebabkan koloni cendawan tidak tumbuh dari awal inokulasi hingga hari ke-7 setelah inokulasi. Perlakuan konsentrasi $0,05 \%$ dan $0,035 \%$ juga menunjukkan pengaruh yang nyata terhadap kontrol dengan ukuran diameter masing-masing $0,979 \mathrm{~cm}$ dan $1,833 \mathrm{~cm}$ secara berturut-turut. Sedangkan, untuk perlakuan $0,02 \%$ dengan diameter 3,027 $\mathrm{cm}$ hasil analisis statistik menunjukkan tidak adanya pengaruh nyata terhadap kontrol bahkan pada hari ke-7 setelah inokulasi ukuran diameter koloni lebih besar dibanding kontrol. Tabel data diameter rata-rata miselium cendawan hasil uji statistik dengan Uji Jarak Berganda Duncan, sebagai berikut.

Tabel 3. Diameter rata-rata koloni cendawan Alternaria solani pada uji daya hambat minyak daun cengkeh

\begin{tabular}{cccccccc}
\hline \multirow{2}{*}{ Perlakuan } & \multicolumn{7}{c}{ Diameter rata-rata miselium $(\mathrm{cm})$ pada } \\
\cline { 2 - 8 } & $1 \mathrm{HSI}$ & $2 \mathrm{HSI}$ & $3 \mathrm{HSI}$ & $4 \mathrm{HSI}$ & $5 \mathrm{HSI}$ & $6 \mathrm{HSI}$ & $7 \mathrm{HSI}$ \\
\hline $0,000 \%$ & $0,377 \mathrm{~b}$ & $1,005 \mathrm{c}$ & $1,753 \mathrm{c}$ & $2,15 \mathrm{~d}$ & $2,404 \mathrm{~d}$ & $2,670 \mathrm{~d}$ & $2,974 \mathrm{~d}$ \\
$0,020 \%$ & $0,053 \mathrm{a}$ & $0,375 \mathrm{~b}$ & $0,911 \mathrm{~b}$ & $1,458 \mathrm{c}$ & $1,924 \mathrm{~d}$ & $2,486 \mathrm{~d}$ & $3,027 \mathrm{~d}$ \\
$0,035 \%$ & $0,000 \mathrm{a}$ & $0,067 \mathrm{a}$ & $0,262 \mathrm{a}$ & $0,691 \mathrm{~b}$ & $0,927 \mathrm{c}$ & $1,357 \mathrm{c}$ & $1,833 \mathrm{c}$ \\
$0,050 \%$ & $0,000 \mathrm{a}$ & $0,022 \mathrm{a}$ & $0,047 \mathrm{a}$ & $0,226 \mathrm{a}$ & $0,378 \mathrm{~b}$ & $0,629 \mathrm{~b}$ & $0,979 \mathrm{~b}$ \\
$0,065 \%$ & $0,000 \mathrm{a}$ & $0,000 \mathrm{a}$ & $0,000 \mathrm{a}$ & $0,000 \mathrm{a}$ & $0,000 \mathrm{a}$ & $0,000 \mathrm{a}$ & $0,000 \mathrm{a}$ \\
\hline
\end{tabular}

Keterangan: Angka-angka yang diikuti oleh huruf yang sama pada kolom yang sama memiliki hasil yang tidak berbeda nyata menurut uji jarak berganda Duncan pada taraf kesalahan 5\%.

Ditinjau dari data diameter koloni yang diperoleh, perlakuan konsentrasi $0,020 \%$ pada 1 HSI hingga 4 HSI $(0,053 \mathrm{~cm}$ menjadi $1,458 \mathrm{~cm})$ menunjukkan perbedaan yang nyata dengan kontrol. Namun, karena miselium terus mengalami pertumbuhan dan diameter koloni meningkat setiap hari sehingga pada 5 HSI sampai 7 HSI menjadi berbeda tidak nyata dengan kontrol. Bahkan pada 7 HSI $(3,027 \mathrm{~cm})$ mengalami peningkatan hingga lebih besar ukuran diameter koloninya dengan kontrol (diameter 2,974 cm). Bertambahnya ukuran diameter koloni pada beberapa perlakuan dari 1 HSI hingga 7 HSI menunjukkan bahwa kemampuan minyak daun cengkeh dalam menghambat pertumbuhan miselium cendawan A. solani efektivitasnya menurun sehingga nilai persentase penghambatannya juga berkurang. Persentase penghambatan 
perlakuan konsentrasi $0,020 \%$ pada 1 HSI hingga 4 HSI menurun dari angka $86 \%$ menjadi $32 \%$, semakin menurun pada 5 HSI menjadi $20 \%$ hingga mencapai nilai negatif sebesar $-2 \%$ pada 7 HSI. Perlakuan $0,035 \%$ berbeda nyata dengan kontrol dari 1 HSI sampai 7 HSI, miselium cendawan mulai tumbuh pada 2 HSI dengan diameter 0,067 $\mathrm{cm}$ dan meningkat hingga $1,833 \mathrm{~cm}$ pada 7 HSI. Nilai persentase penghambatannya pun menurun dari $100 \%$ hingga 38\%. Perlakuan $0,050 \%$ juga berbeda nyata dengan kontrol dari 1 HSI sampai 7 HSI pertumbuhan diameter koloni meningkat dan terjadi penurunan persentase penghambatan. Miselium cendawan mulai tumbuh pada 2 HSI dengan diameter $0,022 \mathrm{~cm}$ meningkat $\mathrm{h}$ ingga $0,979 \mathrm{~cm}$ pada $7 \mathrm{HSI}$, persentase penghambatan juga menurun dari $100 \%$ menjadi $67 \%$. Berbeda dari perlakuan lainnya, pada perlakuan $0,065 \%$ tidak terjadi pertumbuhan miselium sehingga persentase penghambatan konstan sebesar $100 \%$.

Berdasarkan data diameter koloni dan persentase penghambatannya dapat disimpulkan bahwa semakin tinggi konsentrasi yang diberikan maka daya hambat minyak daun cengkeh terhadap pertumbuhan miselium cendawan A. solani juga lebih besar, hal tersebut juga berlaku terhadap nilai persentase penghambatan setiap perlakuan. Kecuali, pada perlakuan konsentrasi $0,020 \%$ yang tidak menunjukkan pengaruh positif dalam menghambat pertumbuhan koloni cendawan A. solani. Berikut ditampilkan data persentase penghambatan dari masing-masing perlakuan.

Tabel 4. Pengaruh perbedaan konsentrasi minyak daun cengkeh terhadap penghambatan pertumbuhan koloni cendawan Alternaria solani

\begin{tabular}{cccccccc}
\hline \multirow{2}{*}{ Perlakuan } & \multicolumn{6}{c}{ Persentase penghambatan pertumbuhan koloni (\%) pada } \\
\cline { 2 - 8 } & 1 HSI & 2 HSI & 3 HSI & 4 HSI & 5 HSI & 6 HSI & 7 HSI \\
\hline $0,020 \%$ & 86 & 63 & 48 & 32 & 20 & 7 & -2 \\
$0,035 \%$ & 100 & 93 & 85 & 68 & 61 & 49 & 38 \\
$0,050 \%$ & 100 & 97 & 97 & 89 & 84 & 76 & 67 \\
$0,065 \%$ & 100 & 100 & 100 & 100 & 100 & 100 & 100 \\
\hline
\end{tabular}

Kemampuan daya hambat yang dimiliki minyak daun cengkeh dipengaruhi oleh kandungan senyawa bioaktif eugenol. Senyawa eugenol merupakan senyawa utama yang terkandung dalam minyak daun cengkeh dengan jumlah berkisar antara 70$80 \%$ (Musta \& Nurliana, 2019). Kandungan eugenol yang dimiliki bisa mencapai 72 $90 \%$, selain itu minyak daun cengkeh juga mengandung asetil eugenol, betacaryophyllene dan vanillin, asam krategolat, tanin, asam galotanat, metil salisilat, flavonoid, dan triterpenoid (Bhowmik et al., 2012). Hal tersebut didukung oleh pernyataan Manohara dan Noveriza (1999) dalam Febriyono dan Djatmiko (2019) yang menyebutkan bahwa minyak daun cengkeh mengandung eugenol dan senyawa ini bersifat antifungi karena mampu merusak dinding sel cendawan dengan cara mengganggu penyusun dinding sel pada cendawan tersebut.

Dinding sel cendawan adalah struktur dinamis yang melindungi protoplas cendawan dari guncangan dan definisi osmotik eksternal morfogenesis cendawan. Mekanisme kerja eugenol sebagai antifungi adalah dengan mengganggu sintesis ergosterol yang merupakan komponen penting penyusun dinding sel pada cendawan sehingga membran sel rusak dan fungsinya menurun (Pereira et al., 2013). Ergosterol merupakan sterol yang paling umum ditemukan pada membran sel 
cendawan. Sterol bertanggung jawab terhadap rigiditas (kekakuan), stabilitas membran dan pertahanan terhadap tekanan fisik (Loeffler and Stevens, 2003 dan Mukhopadhyay et al., 2004 keduanya dalam Candrasari, 2014). Maka apabila ergosterol tidak terbentuk kehidupan cendawan tersebut akan terganggu karena membran yang merupakan pelindung sel cendawan itu sendiri mengalami kerusakan dan penurunan fungsi.

\section{SIMPULAN}

1. Minyak daun cengkeh mampu menghambat pertumbuhan miselium cendawan Alternaria solani, sedangkan ekstrak daun pepaya tidak memiliki pengaruh dalam menghambat pertumbuhan miselium jamur A. solani.

2. Minyak daun cengkeh pada konsentrasi $0,065 \%$ dapat menghambat pertumbuhan miselium cendawan $A$. solani dengan persentase penghambatan sebesar $100 \%$.

\section{SARAN}

1. Perlu dilakukan penelitian untuk mengetahui kemampuan minyak daun cengkeh dalam menghambat sporulasi cendawan A. solani.

2. Diperlukan penelitian mengenai aktivitas antifungi minyak daun cengkeh dalam menghambat pertumbuhan cendawan A. solani secara in vivo (skala laboraturium) maupun secara in planta (di lapangan).

\section{UCAPAN TERIMAKASIH}

Ucapan terimakasih disampaikan kepada pihak Laboratorium Fakultas Pertanian Universitas Siliwangi yang telah menyediakan fasilitas dalam pelaksanaan penelitian ini dan juga kepada pihak Balai
Penelitian Tanaman Sayuran (Balitsa) yang telah menyediakan biakan murni cendawan Alternaria solani sehingga penelitian ini dapat terlaksana dengan lancar.

\section{DAFTAR PUSTAKA}

A'yun, Q., \& Laily, A. N. (2015). Analisis fitokimia daun pepaya (Carica papaya L.) di balai penelitian tanaman aneka kacang dan umbi, Kendalpayak, Malang. Prosiding Seminar Nasional Konservasi dan Pemanfaatan Sumber Daya Alam, Surakarta, 13 Januari 2015.

Achmad, \& Suryana, I. (2009). Pengujian aktivitas ekstrak daun sirih (Piper betle Linn.) terhadap Rhizoctonia sp. secara In vitro. Buletin Penelitian Tanaman Rempah dan Obat, 20(1), 92-98.

Adhikari, P., Oh, Y., \& Panthee, D. R. (2017). Current status of early blight resistance in tomato: An update. International Journal of Molecular Sciences, 18(10), 1-22. https://doi.org/10.3390/ijms18102019

Alma, M. H., Ertaş, M., Nitz, S., \& Kollmannsberger, H. (2007). Chemical composition and conte nt of essential oil from the bud of cultivated Turkish clove (Syzygium aromaticum L.). BioResources, 2(2), 265-269.

Andries, J. R., Gunawan, P. N., \& Supit, A. (2014). Uji efek anti bakteri ekstrak bunga cengkeh terhadap bakteri Streptococcus mutans secara in vitro. Jurnal e-GIGI, 2(2).

Ardina, Yustine. (2007). Pengembangan formulasi sediaan gel antijerawat serta penentuan konsentrasi hambat minimum ekstrak daun pepaya (Carica papaya linn.). Tesis. Sekolah Farmasi. Institut Teknologi Bandung.

Ariani, K. (2016). Uji efektivitas ekstrak daun pepaya (Carica papaya L.) sebagai fungisida alami terhadap jamur Colletotrichum capsici (Syd.) Butler \& Bisby penyebab penyakit antraknosa 
pada tanaman cabai merah (Capsicum annuum L .). Skripsi. Jurusan Biologi. Universitas Lampung. Bandar Lampung.

Ariyanti, R., Yenie, E., \& Elystia, S. (2017). Pembuatan Pestisida nabati dengan cara estraksi daun pepaya dan belimbing wuluh. Jom FTEKNIK, 4(2), 1-9. https://doi.org/10.13989/j.cnki.05176611. 2015.10.011

Arneti, Liswarni, Y., \& Edriwilya, R. (2020). Efektivitas Ekstrak daun pepaya secara in vitro terhadap Colletotrichum gloeosporioides penyebab penyakit antraknosa pada tanaman cabai. Jpt: Jurnal Proteksi Tanaman (Journal of Plant Protection), 4(1), 1-10. https://doi.org/10.25077/jpt.4.1.110.2020

Asmaliyah, H., Etik Erna Wati, Utami, S., et al. (2010). Pengenalan tumbuhan penghasil pestisida nabati dan pemanfaatannya secara tradisional. Palembang: Kementrian Kehutanan.

Balafif, F. F., Satari, M. H., \& Dhianawaty, D. (2017). Aktivitas Antijamur fraksi air sarang semut myrmecodia pendens pada Candida albicans ATCC 10231. Majalah Kedokteran Bandung, 49(1), 28-34. https://doi.org/10.15395/mkb.v 49n1.984

Balouiri, M., Sadiki, M., \& Ibnsouda, S. K. (2016). Methods for in vitro evaluating antimicrobial activity: A review. Journal of Pharmaceutical Analysis, 6(2), 71-79. https://doi.org/10.1016/j.jpha.2015.11.005

Baskaran, C., Bai, V. R., Velu, S., \& Kumaran, K. (2012). The efficacy of Carica papaya leaf extract on some bacterial and a fungal strain by well diffusion method. Asian Pacific Journal of Tropical Disease, 2(SUPPL2), 658662.

Bhowmik, D., Kumar, K. P. S., Yadav, A., Srivastava, S., Paswan, S., \& Dutta, A. S. (2012). Recent trends in indian traditional herbs Syzygium aromaticum and its health benefits. Journal of Pharmacognosy and Phytochemistry, 1(1), 6-17.
Bustaman, S. (2011). Potensi pengembangan minyak daun cengkih sebagai komoditas ekspor Maluku. Jurnal Litbang Pertanian, 30(4), 132-139.

Cahyono, B. (2008). Tomat, Usaha Tani dan Penanganan Pasca Panen. Kanisius.

Candrasari, D. S. (2014). Kajian molekuler resistensi Candida albicans terhadap antifungi. Jurnal Farmasi Sains dan Komunitas, 1(11), 43-47.

Dadang, \& Prijono, D. (2008). Insektisida Nabati: Prinsip, Pemanfaatan dan Pengembangan. Bogor: Departemen Proteksi Tanaman, Institut Pertanian Bogor.

Everhart, C. (2010). The Complete Guide to Growing Tomatoes. Atlantic Publishing Group Inc.

Fauzi'ah, L., \& Wakidah, M. (2019). Extraction of papaya leaves (Carica papaya L.) using ultrasonic cleaner. Eksakta, 19(1), 35-45. https://doi.org/ 10.20885/eksakta.vol19.iss1.art

Febriyono, W., \& Djatmiko, H. A. (2019). Pengaruh Empat Minyak Atsiri terhadap Jamur Agens Pengendali Hayati. Biofarm, 15(2), 71-79. https://doi.org/ 10.31941/biofarm.v15i2.1195

Gomez, K. A., \& Gomez, A. A. (2015). Prosedur statistik untuk penelitian pertanian (Second). UI Press.

Harjana, T. (2009). Pemanfaatan daun pepaya (Carica papaya L.) untuk pertumbuhan dan efeknya pada gambaran histologi usus halus tikus putih (Rattus norvegicus). Prosiding Seminar Nasional Penelitian, Pendidikan dan Penerapan MIPA. Yogyakarta, 16 Mei 2009.

Hartati, S. Y. (2012). Efikasi formula fungisida nabati terhadap penyakit bercak daun jahe Phyllosticta sp. Balai Penelitian Tanaman Rempah dan Obat, 24(1), 42-48. 
Hertanti, S. A. (2019). Pengaruh konsentrasi ekstrak daun pepaya (Carica papaya L.) terhadap pertumbuhan Candida albicans plat resin akrilik heat cured. Skripsi. Fakultas Kedoketran Gigi. Universitas Muhammadiyah Semarang.

Irfan, M. (2016). Uji pestisida nabati terhadap hama dan penyakit tanaman. Jurnal Agroteknologi, $\quad 6(2), \quad 39$. https://doi.org/10.24014/ja.v6i2.22 39

Istifadah, N., \& Hakim, N. (2017). kemampuan kompos dan kompos plus untuk meningkatkan ketahanan tanaman tomat terhadap penyakit bercak coklat (Alternaria solani Sor.). Agrikultura, 28(3), 111-117.

Jones, J. B. (2007). Tomato Plant Culture (2nd Edition). CRC Press.

Kalay, A. M., Patty, J., \& Sinay, M. (2015). Perkembangan Alternaria solani pada tiga varietas tanaman tomat. Agrikultura, 26(1), 1-6.

Kardinan, A. (2011). Penggunaan pestisida nabati sebagai kearifan lokal dalam pengendalian hama tanaman menuju sistem pertanian organik. Pengembangan Inovasi Pertanian, 4(4), 262-278.

Mahatriny, N. N., Payani, N. P. S., Oka, I. B. M., \& Astuti, K. W. (2014). Skrining fitokimia ekstrak etanol daun pepaya (Carica papaya L.) yang diperoleh dari Daerah Ubud, Kabupaten Gianyar, Bali. Jurnal Farmasi Udayana, 3(1), 8-13.

Marchese, A., Barbieri, R., Coppo, E., et al. (2017). Antimicrobial activity of eugenol and essential oils containing eugenol: A mechanistic viewpoint. Critical Reviews in Microbiology, 43(6), 668-689. https://www.ncbi.nlm.nih.gov/pubmed/28 346030

Milind, P., \& Gurditta. (2011). Basketful benefits of papaya. International Research Journal of Pharmacy, 2(7), 612.
Mukerji, K. G. (2004). Fruit and Vegetables Diseases. Kluwer Academic Publishers.

Munif, A., Wiyono, S., \& Suwarno. (2012). Isolasi bakteri endofit asal padi gogo dan potensinya sebagai agens biokontrol dan pemacu pertumbuhan. Jurnal Fitopatologi Indonesia, 8(3), 57-64.

Musta, R., \& Nurliana, L. (2019). Studi kinetika efektifitas minyak daun cengkeh (Syzigium aromaticum) sebagai antifungi Candida albicans. Indo. J. Chem. Res., 6(2), 107-114. https://doi.org/10.30598/ /ijcr.2019.6-rus

Nashwa, S. M. A., \& Abo-Elyou, K. A. M. (2012). Evaluation of various plant extracts against the early blight disease of tomato plants under greenhouse and field conditions. Plant Protection Science, 48(2), 74-79. https://doi.org/10.17221/14 /2011-pps

Nugroho, A., Heryani, H., Choi, J. S., \& Park, H. J. (2017). Identification and quantification of flavonoids in Carica papaya leaf and peroxynitrite-scavenging activity. Asian Pacific Journal of Tropical Biomedicine, 7(3), 208-213. https://doi.org/10.1016/j.apjtb.2016.12.009

Nurdjannah, N. (2004). Diversifikasi penggunaan cengkeh. Jurnal Perspektif, $3(2), 61-70$.

Nuryanti, S. (2017). Aktivitas antifungi sari daun pepaya (Carica papaya L.) terhadap Candida albicans. As-Syifaa, 09(02), 137-145.

Nwinyi, Chukwuemeka, O., \& Busola Anthonia, A. (2010). Antifungal effects of pawpaw seed extracts and papain on post harvest Carica papaya L. fruit rot. African Journal of Agricultural Research, 5(12), 1531-1535.

Oktofani, L. A., \& Suwandi, J. F. (2019). Potensi tanaman pepaya (Carica papaya L.) sebagai antihelmintik. Majority, 8(1), 246-250. 
Pereira, F. D. O., Mendes, J. M., \& Lima, E. D. O. (2013). Investigation on mechanism of antifungal activity of eugenol against Trichophyton rubrum. Medical Mycology, 51(5), 507-513. https://doi.org/10.3109/13693786.2012. 742966

Pratiwi, L., Rachman, M. S., \& Hidayati, N. (2016). Ektraksi Minyak atsiri dari bunga cengkeh dengan pelarut etanol dan nheksana. University Research Colloquium, 2, 655-661.

Purnomo, D. (2008). Aplikasi getah dua genotipe pepaya betina sebagia biofungisida untuk mengendalikan penyakit antraknosa (Colletotrichum capsici (Syd.) Bult. Et. Bisby) pada cabai merah besar (Capsicum annum L.). Skripsi. Fakultas Pertanian. Institut Pertanian Bogor.

Qur'ani, H. (2019). Formulasi sediaan anti jerawat ekstrak daun pepaya (Carica papaya L.) dalam bentuk gel. Skripsi. Universitas Katolik Widya Mandala. Surabaya.

Radilla, Nada. (2019). Uji efektivitas minyak atsiri kunyit dan cengkeh dalam penghambatan patogen Botryodiplodia sp. secara in vitro. Skripsi. Fakultas Kehutanan. Institut Pertanian Bogor.

Ragasa, C., \& Tsai, P. (2009). Antimicrobial terpenoids from Erigeron sumatrensis. NRCP Research Journal, 10(1), 27-32.

Ramadhona, R. (2016). Efektivitas ekstrak daun pepaya dalam pengendalian kutu daun pada fase vegetatif tanaman terung. Skripsi. Fakultas Pertanian. Universitas Bengkulu.

Rana, I. S., Rana, A. S., \& Rajak, R. C. (2011). Evaluation of antifungal activity in essential oil of the Syzygium aromaticum (L.) by extraction, purification and analysis of its main component eugenol. Brazilian Journal of Microbiology, 42(4), 1269-1277.
Ravikumar, M. C., Singh, H., \& Garampalli, R. H. (2016). Comparative evaluation of long-term storage techniques on viability and virulence of Alternaria solani. Journal of Taibah University for Science, 10(4), 607-613. https://doi.org/10.1016/ j.jtusci.2015.12.008

Roy, C. K., Akter, N., Sarkar, M. K. I., et al. (2019). Control of early blight of tomato caused by Alternaria solani and screening of tomato varieties against the pathogen. The Open Microbiology Journal, 13(1), 41-50. https://doi.org/ 10.2174/1874285801913010041

Saenong, M. S. (2016). Tumbuhan Indonesia potensial sebagai insektisida nabati untuk mengendalikan hama kumbang bubuk jagung (Sitophilus spp.). Jurnal Penelitian dan Pengembangan Pertanian, 35(3), 131-142. https://doi. org/10.21082/jp3.v35n3.2016.p131-142

Salma, Arina. (2020). Uji daya hambat minyak cengkeh (Syzygium aromaticum L.) terhadap cendawan patogen pada tanaman cabai (Capsicum annuum L.) secara in vitro. Skripsi. Fakultas Pertanian. Universitas Siliwangi. Tasikmalaya.

Santoso, A. B. (2018). Upaya mempertahankan eksistensi cengkeh di Provinsi Maluku melalui rehabilitasi dan peningkatan produktivitas. Jurnal Penelitian dan Pengembangan Pertanian, 37(1), 26-32.

Setiaji, A. (2009). Efektifitas ekstrak daun pepaya Carica papaya L. untuk pencegahan dan pengobatan ikan lele dumbo Clarias $s p$. yang diinfeksi bakteri Aeromonas hydrophila. Skripsi. Fakultas Perikanan dan Ilmu Kelautan. Institut Pertanian Bogor.

Setiawan, H., \& Oka, A. A. (2015). Pengaruh variasi dosis larutan daun pepaya (Carica papaya $\mathrm{L}$.) terhadap mortalitas hama kutu daun (Aphis craccivora) pada tanaman kacang panjang (Vigna sinensis L.) sebagai sumber belajar biologi. 
BIOEDUKASI (Jurnal Pendidikan

Biologi), 6(1), 54-62.

https://doi.org/10.24127/bioedukasi.v6i1.158

Setiawan, W. (2019). Kolonisasi dan cara kerja Aureobasidium pullulans Dmg 30 DEP dalam Pengendalian Hayati Penyakit Bercak Cokelat pada Tanaman Tomat. Tesis. Sekolah Pascasarjana. Institut Pertanian Bogor.

Shahin, E. A., \& Shepard, J. F. (1979). An efficient technique for inducing profuse sporulation of alternaria species. Phytopathology, 69(6), 618-620.

Singkoh, M., \& Katili, D. Y. (2019). Bahaya pestisida sintetik (sosialisasi dan pelatihan bagi wanita kaum ibu Desa Koka Kecamatan Tombulu Kabupaten Minahasa). JPAI: Jurnal Perempuan dan Anak Indonesia, 1(1), 5-12.

Sopialena, Sofyan, A., \& Alfansuri, A. R. (2017). Potensi penggunaan jamur Gliocladium virens M. untuk mengendalikan penyakit bercak coklat pada tanaman tomat (Lycopersicum esculentum L.). Prosiding Seminar Nasional, "Pengelolaan, Pengembangan dan Pemanfaatan Sumber Daya Genetik (SDG) Pertanian dan Peternakan untuk Mendukung Ketersediaan Pangan yang Berkelanjutan". Samarinda, 6-7 November 2017.

Suhartini, Suryadarma, I., \& Budiwari. (2017). Pemanfaatan pestisida nabati pada pengendalian hama Plutella xylostella tanaman sawi (Brassica juncea 1.) menuju pertanian ramah lingkungan. Jurnal Sains Dasar, 6(1), 36-43. https://doi.org/10.21831/jsd.v6i 1.12998

Suleiman, M. N. (2010). Fungitoxic activity of neem and pawpaw leaves extracts on Alternaria solani, causal organism of yam rots. Advances in Environmental Biology, 4(2), 159-161.

Syamsuddin, Ilyas, S., Manohara, D., \& Sudarsono. (2007). Efektifitas daya hambat minyak nabati terhadap pertumbuhan koloni beberapa patogen terbawa benih cabai secara in vitro. Agrista, 11(2), 81-91.

Talahatu, D. R., \& Papilaya, P. M. (2015). Pemanfaatan ekstrak daun cengkeh (Syzygium aromaticum L .) sebagai herbisida alami terhadap pertumbuhan gulma rumput teki (Cyperus rotundus L.). Biopendix, 1(2), 160-170.

Tampubolon, K., Sihombing, F. N., Purba, Z., et al. (2018). Potensi metabolit sekunder gulma sebagai pestisida nabati di Indonesia. Kultivasi, 17(3), 683-693. https://doi.org/10.24198/kultivasi.v17i3.1 8049

Towaha, J. (2012). Manfaat eugenol cengkeh dalam berbagai industri di Indonesia. Perspektif, 11(2), 79-90.

Wahyuni, Nunik. (2004). Respon Alternaria solani, penyebab penyakit bercak coklat pada tomat, terhadap ekstrak daun cengkeh dan pala secara in vitro. Skripsi. Fakultas Pertanian. Institut Pertanian Bogor.

Widhayasa, B., Sastrahidayat, I. R., \& Syamsuddin, D. (2014). Perkecambahan jamur Alternaria solani dan infeksinya pada sembilan varietas tomat. $\mathrm{Hpt}, 2(3)$, 102-108.

Zulkipli, S., Marsuni, Y., \& Rosa, H. O. (2018). Uji lapangan beberapa pestisida nabati untuk menekan perkembangan penyakit antraknosa pada tanaman cabai besar. Proteksi Tanaman Tropika, 1(02), 32-34. 